\title{
CESIS
}

Electronic Working Paper Series

(Forthcoming Industry and Innovation)

Paper 101.

\section{Specialization of Regions and Universities The New Versus the Old ${ }^{1}$}

\author{
October 2007 \\ Pontus Braunerhjelm²
}

\footnotetext{
${ }^{1}$ Helpful comments have been provided by participants at the $2^{\text {nd }}$ Workshop on the Process of Reform of University Systems in Venice 2006, the Schumpeter 2006 meeting and two anonymous referees. I also like to thank the Marianne and Marcus Wallenberg Foundation for generous financial support.

${ }^{2}$ Leif Lundblad's Chair in International Business and Entrepreneurship, The Royal Institute of Technology, Stockholm, SE-100 4486 Stockholm, Sweden. Phone: +46 8 7909114, fax: +46 8 4117436, e-mail; pontusb@infra.kth.se.
} 
Abstract

This paper analyzes whether there is a correspondence between a university's research specialization and industrial specialization in the region hosting the university, and to what extent universities influences regional productivity. Moreover, the analysis seeks to answer if a difference can be detected between the influences of old and new universities on regional performance. To achieve this end we utilize a unique dataset on spatially disaggregated data for Sweden in the period 1975-1999. A two-step Heckman regression analysis is implemented to examine whether the universities research specialization match regional specialization in production as compared to the average region. The results suggest a correspondence in specialization, as well as positive productivity effects. However, there are also considerable differences across regions, albeit primarily unrelated to the age of the universities.

Keywords: Universities, norms, regional specialization, policies.

JEL: J24; O31; O57 


\section{Introduction}

Which strategies should regions adopt in order to cope with the challenges imposed by increased globalization and competition? The response predominantly seems to revolve around policies that attract, sustain and upgrade knowledge intensive production in the higher range of the value-added chain. ${ }^{3}$ Local universities, with a solid national and, preferably, international reputation is seen as a natural and important node in regional restructuring towards a knowledge based economy.

However, whether the mere presence of a university suffice to spark regional development is less obvious. It depends on why and how universities come into existence, the links to the commercial sectors, traditions and norm within as well as outside the universities (Owen-Smith and Powell 2001; Bercovitz and Feldman 2004). For the U.S. it has been shown that universities often originate in, or co-evolve with, the growth of industries due to increased demand for specific skills and research (Rosenberg and Nelson 1994; Phan and Siegel 2006). However, previous studies has also shown that many universities - in Europe as well

as in the U.S. - have weak or practically non-existent links with the regional or local industry (Clark 1995; Goldfarb and Henrekson 2003).

As a consequence of the assessed importance to increase the interaction between academia and the business sector, a large number of European countries have re-organized their university systems. Responsibilities have been redefined to include a more active role in the commercialization of research. The rationale for this change is the alleged positive experience in the U.S., which goes back to the implementation of the Bayh-Dole Act in 1980, when universities obtained the intellectual property rights (IPRs) to their research results. Still, opinions differ as regards the effect and desirability of introducing a U.S. based system and the 
extent to which the Bayh-Dole legislation actually propelled commercialization of university research (Mowery and Ziedonis 2001, 2002; Arundel and Geuna 2004).

To examine how universities corresponds with regional specialization and their role in prompting knowledge intensive production, the proceeding analysis will implement econometric techniques to estimate whether regional specialization in knowledge-intensive production corresponds to the respective university's specialization in research, and the extent to which labor productivity is influenced by proximity to universities. Unique data crosstabulated on regions and industries will be used in the analysis. The results contributes with new insights into, i) the impact of - and difference between - new and old universities on regional specialization and growth, ii) the importance of a correspondence between universities specialization on one hand, and specialization of the surrounding industrial environment on the other, in order for knowledge spillovers and growth to materialize, iii) the need to improve the microeconomic foundation of regional knowledge spillover models, and iv) the design of economic policies. Thus, the analysis refutes the idea that knowledge nodes - such as universities - automatically induce knowledge spillovers, even after a relatively long time has elapsed.

We believe that Sweden stands out as a particularly interesting case as regards the relationship between public research and commercialization, having emphasized the importance of regional cohesion and using universities to strengthen the regional knowledge base since the 1960s. The analysis covers a time span of almost 30 years and will involve four universities: the two oldest in Sweden (established 1477 and 1666) and two more recently established universities (1969 and 1975), the latter with a clear objective to strengthen the regional economy. If the policy has been successful, it can be expected to be manifest in an expansion of

\footnotetext{
${ }^{3}$ Indications of intensified regional restructuring towards knowledge intensive industries is illustrated in increased branding activities (Medicon Valley, Silicon Glen, Sophia Antipolis, Telecom Valley, etc.) and the
} 
the existing knowledge intensive production, the emergence of new knowledge based production, and increased productivity. The analysis will use different econometric techniques to analyze the effects of universities on the regional specialization and productivity.

The following two sections present a brief survey of previous research that is relevant to the issue we address and the theoretical framework. Thereafter the hypotheses, data and empirical model are introduced, while the results are discussed in the subsequent section. The final sections discuss the role of new universities in regional development and measures to alleviate the weaknesses in the links between university research, and summarizes the overall findings.

\section{Previous research and theoretical framework}

The traditional link between research and its commercial applications has primarily been through the "open science model", i.e. externalities created and disseminated by public research at universities. However, and partly due to the alleged experiences of the Bayh-Dole act (1980) in the U.S., the role of universities has been redefined in the last few decades. Besides the traditional tasks of teaching and conducting research, universities are expected to carry out a more active role in the transformation of academic knowledge into economic knowledge. This so called "third mission" of universities implies a major overhaul of the way in which particularly European universities have traditionally operated and been organized.

The impact of the Bayh-Dole act is however far from undisputed. There is an ongoing debate as to whether the institutional change in the U.S. actually prompted the increase in university patenting, or whether that was already taking place due to substantial increases in research funding, especially in biotechnology, in the late 1970s and the early 1980s. Surveying this strand of the literature, Geuna and Nesta (2006) conclude that there is little evidence 
of university owned intellectual property rights (IPRs) being an efficient device to transfer technologies and know-how to the commercial sector. ${ }^{4}$

It has also been questioned whether the lower numbers of university related patents in Europe can be translated into a lower rate of commercialization. Some studies provide evidence to show that the extent of the commercialization effects of European public research is underestimated. A study on Belgium, Finland, France, Germany and Italy (Balconi et al. 2004) claims that university initiated patents (although not owned by the universities) are considerably higher then previously believed. Similar results are reported by Meyer (2003), Saragossi and von Pottelsbergh de la Potterie (2003), and Azagra and Llerena (2003). Still, one would suspect that the same situation prevails in the U.S., i.e. parts of university-based research are commercialized through different channels outside the universities' realm. ${ }^{5}$ Hence, the view that the impact stretches beyond patents owned by universities is valid. However it is less obvious that this would explain the difference between Europe and the U.S., nor whether the present European system is working satisfactorily.

At the national level the role of higher education and skill composition for growth has been highlighted in previous research (Denison 1968; Rosenberg and Nelson 1994). More recently, the link between universities' influence on commercialization, and the transformation towards a knowledge-based economic development at the regional level, has received an increasing attention (for a survey, see Phan and Siegel 2006). In particular, the instrumental role of the university in producing localized knowledge has been emphasized (Castells 1989;

\footnotetext{
${ }^{4}$ Positive effects are however reported for the U.S. (Link 1996; Caloghirou et al. 2001), for Norway (Gulbrandsen and Smeby 2002) and Belgium (Ranga 2003) in Europe. Other studies claim that the transfer of IPRs had little to do with the increase in commercialization (Mowery et al. 2001; Mowery and Sampat 2001; Mowery and Ziedonis 2001; Nelson 2001, 2002; Mowery and Ziedonis 2002).

${ }^{5}$ The extent of, and channels through which, knowledge is sourced from universities appears to vary with firm and industry characteristics. See for instance Zucker and Darby (1996), Meyer-Krahmer and Schmoch (1998),
} 
Bleaney et al. 1992; Mansfield 1995). The cost of sourcing knowledge seems to be lower the closer to the source, i.e. close to the universities, suggesting that distance is indeed a barrier in accessing knowledge and that there is a spatial dimension to knowledge spillovers (Jaffe et al. 1993; Anselin et al. 1997, 2000; Rosenthal and Strange 2003). ${ }^{6}$ Chesire and Malecki (2004) claim that regional growth is closely associated with the presence of universities and higher education establishments. Similar findings have been presented by Feller (1990), Felsenstein (1996) and Phelps (1998).

Several studies also stress that the impact on regional development, in terms of productivity effects and spillovers, is largest for new universities. ${ }^{7}$ Examining 14 regions in seven European countries Boucher et al. (2003) reached this conclusion. The results are corroborated in an analysis on Swedish data, where a positive association is found over a 14-year period between growth at the municipal level and the presence of Swedish universities, colleges and technical institutes (Andersson et al. 2004). One conclusion drawn by the authors is that the decentralization of universities has spurred regional growth (see also Bleaney et al. 1992; Caniels 2000), suggesting that the establishment of new universities is an important ingredient in a strategy to augment regional development. Thus, the policy conclusion is obvious: establishment of a university leads to knowledge spillovers, enhanced productivity and growth, and could be instrumental in shifting declining or stagnant regions into more prosperous trajectories.

Hall et al. (2000), Fontana et al. (2002), Mohnen and Hoareau (2002), Arundel and Geuna (2004) and Geuna et al. (2006).

${ }^{6}$ Anselin et al. (1997) stress the differences across industries. See Feldman (1999) for a survey of the spillover literature. The role of proximity for innovation is addressed by Kline and Rosenberg (1987), Acs et al. (1992) and Arundel and Geuna (2004).

${ }^{7}$ Note that Franklin et al. (2001) report the opposite results: older universities were found to be more entrepreneurial and more open. 
Other studies focus on the network aspects and the importance of embedding universities in an environment conducive to knowledge diffusion, where entrepreneurship, support functions and the institutional setting are important components (Keane and Allison 1999; Boucher et al. 2003). The capacity of regions to absorb new knowledge ("learning regions") and convert knowledge into products is argued to be as crucial, as is the role played by universities and "institutional" thickness. ${ }^{8}$ Hence, according to previous research, universities constitute important nodes in regional development and are preponderant in knowledge intensive production (Hotz-Hart 2000).

A conspicuous feature of these studies is their use of different theoretical and empirical approaches to evaluate the regional effects of universities. For instance, Florax (1992) and Bleaney et al. (1992) aims at estimating the influence of the expenditure multiplier (universities' procurement, salaries, etc.) on regional growth but ignores knowledge spillovers while Boucher et al. (2003: 887) “.....examine how local institutional networks can embed universities into the region to promote a learning environment, develop skills and build resources for competitiveness and social cohesion". Andersson et al. (2004) undertake an interesting analysis where they implement fixed effect regressions to examine how local (municipalities) labor productivity is influenced by the presence of universities as measured by enrolled students and university-based researchers, distributed on new and old universities (dividing line between old and new is 1977). They find a significant and positive effect for all of the imposed explanatory variables on local growth.

The study by Andersson et al. (2004) differs from the one pursued here in several ways. First, they primarily aim at examining the relationship between education levels and local productivity effects, while the current analysis focuses at the impact of universities on

\footnotetext{
${ }^{8}$ See Amin and Thrift (1994), Armstrong (1997), Autio and Yli-Renko (1998), Thanki (1999), Lundvall and Johnson (1994), Maskell and Tornquist (1999) and Karlsson and Zhang (2001).
} 
regional specialization and productivity effects. In particular, the analysis presented in this paper emphasizes spillovers to a limited number of more R\&D-intensive industries. Second, they also implement a different regional definition and classify the universities of Linköping and Umeå into the same age category as Lund University and Uppsala University. Finally, they chose an econometric technique where the fixed effects pick up all explanatory powers with the exception of the university-based variable, whereas one of the objectives of the current study is to identify the impact of other variables as well.

\section{Theoretical framework}

As suggested by the above literature review, the economics of universities is associated with several theoretical models. From the more aggregate perspective, a relevant theoretical structure is provided by the endogenized (knowledge-based) growth models, stressing the role of knowledge spillover for economic development and growth (Romer 1986, 1990, 1994;

Schmitz 1989; Aghion and Howitt 1992, 1998; Acs et al. 2004). Other obvious candidates are evolutionary models based on learning and routines, or the innovation system approach emphasizing the systemic character of a well-functioning environment in order to convert knowledge into useful products (Lundvall 1982; Nelson and Winter 1982). Similarly, institutional economics would also serve as theoretical framework for the issues addressed in this paper, where incentive structures, property rights and credible enforcement mechanism are at focus.

Thus, the relationship between academic research and the commercial sectors is not captured by one specific model, rather, as argued by Antonelli (2007), a unifying theory is needed to understand endogenous change and regional development such as complexity theory. Hence, an eclectic approach is proposed. However, even though it draws on several veins in economics, the cornerstones originate in the systemic approach. Path-dependence is a key feature in understanding the dynamics and interplay between links in complex economic sys- 
tems. More precisely, the basic assumptions of complexity theory are: i) Heterogeneous agents characterized by distinctive different abilities, ii) proximity and density across agents matter and impact local performance, iii) knowledge is primarily localized, implying that agents are partially informed and bounded by local knowledge, iv) agents are primarily engaged in local networks, transactions, feedbacks, etc. and hence exposed to local pecuniary and non-pecuniary externalities, albeit related to (macro) systems at a higher dimension, $v$ ) based on individual characteristics and local conditions, creative agents react to changes in the environment or the system in which they are active, and vi) the outcome of individual agents depend on the web of interactions, i.e. systemic interdependence prevail.

Specific features of complex systems are, according to Rosser (1999), non-ergodicity, (small shocks affect the long-run dynamics), phase transition (qualitative characteristics of the system are sensitive to small parametric changes), and emergent properties (properties apply at a specific level of aggregation). Thus, complex systems aims at distinctively link the micro features to the macro outcome.

Even though the model no doubt captures the essence of the forces that propel regional specialization, it is too overarching for the purposes of the present paper. Rather, the issue addressed in this paper focuses on some of the critical building blocks in the complexity model, primarily the regional imprint of regional knowledge nodes, the diffusion of knowledge, and regional absorption/learning, as witnessed from the pattern of specialization and productivity. These elements in the complexity model originate in contributions by Arrow (1962) who introduced learning as critical ingredient to the growth process, the endogenous growth literature referred to above, but also more recent work in evolutionary economics as well as in sociology (the importance of norms). Notwithstanding their seminal contributions to economics, 
these previous models disregard individual as well as regional differences, and how they are systematically related. $^{9}$

Thus, the weaknesses of these models are associated with the lack of a system structure that model knowledge transfers through the interconnections between different agents: firms, service providers, governmental agencies, universities, etc. Learning and the role of systems need to be better integrated into mainstream growth theory. The successful commercialization of new knowledge or new technologies is the fragile result of a complex set of necessary and complementary conditions where firms adapt continually to the changing conditions of their environment (Metcalfe et al. 2006; Braunerhjelm and Feldman 2006).

Complexity theory hence suggests that the establishment of a regional knowledge node - such as a university - does not suffice to spark regional knowledge spill-over that are converted into new products and regional growth. To achieve this end, universities have to be embedded in an environment defined by functional systems that can absorb such knowledge spillover through different channels and feedbacks between regional actors. A correspondence between regional specialization in production and the respective university's research specialization, as well as a positive relationship between universities and regional growth, can be expected to reflect the existence of such regional absorption capacities.

\footnotetext{
${ }^{9}$ In particular, the endogenous growth models failed to model the way in which knowledge is converted (spills over) into commercially viable products. Hence, the main mechanism to promote growth - knowledge spillovers - remains exogenous. This shortcoming was to some extent remedied in the subsequent neo-Schumpeterian models (Aghion and Howitt 1992, 1998; Aghion and Griffith 2005). Still, these models are constrained to a very particular form of entry and spillover mechanism (R\&D-races).
} 


\section{Hypotheses, data and empirical model}

\section{Background - the regional setting}

Of the four Swedish universities included in the analysis, two (Linköping University and Umeå University) were established quite recently (1975 and 1969), whereas Lund University and Uppsala University are the two oldest Swedish universities, founded in 1666 and 1477, respectively. ${ }^{10}$ The 1993 the university reform implied that universities should actively get involved in the diffusion and commercialization of research. To achieve this end holding companies were established at all Swedish universities in the following years, with a modest initial endowment of governmental funds (about 550000 Euro). ${ }^{11}$

The four universities are located in different parts of Sweden. Lund University is situated in the very south, while Umeå is located in the far north about 1750 kilometers from Lund. Uppsala university is in the east of Sweden at a distance of 550 kilometers from Lund and about 70 from Stockholm, Sweden's capitol city, while Linköping university is located approximately 300 kilometers from Lund. This geographical distribution basically mirrors the distribution of population in Sweden, i.e. it is relatively sparsely populated north of Uppsala.

The cities where these universities are located differ somewhat in size, stretching from about 90000 inhabitants in Umeå to 140000 in Uppsala. Moreover, the environment in which the universities are embedded also differs; all of them have an adjacent science park of which Mjärdevi in Linköping and Ideon in Lund appear to be the most successful. Uppsala University, on the other hand, has a long tradition of cooperating with large pharmaceutical firms, particularly Pharmacia. In the mid-1990s Pharmacia was acquired by Upjohn, a U.S. firm that relocated most of their activities to other countries, resulting in the emergence of a small firm dominated biotechnology/biomedical cluster. As regards the industrial base it

\footnotetext{
${ }^{10}$ Altogether Sweden has three private and 14 public universities.
} 
seems to be least developed in the Umeå region. Figures $1 \mathrm{a}$ and $1 \mathrm{~b}$ indicate the extent to which the universities are embedded in a commercial environment relating to the fields of Drugs and medicines and Office and computing machinery, measured as the number of employees in those regions compared to the average Swedish region.

The younger universities are approximately the same size in terms of students (full time equivalents), about 18000 students, while Lund (27 000) and Uppsala (22 000) are somewhat bigger. All the universities undertake research in the medical and engineering fields; however, research in the former field is more pronounced in Uppsala and Umeå. Linköping University in particular has a stronger position then the other universities in engineering, whereas research in Lund University is relatively evenly split between the medical and engineering faculties (Table 1). In absolute terms the universities of Lund, Umeå and Uppsala have about the same numbers of full-time equivalent researchers in their medical faculties, approximately 40 percent more then in Linköping. In engineering the research staff at Lund University and Linköping University are considerably larger, compared to the two other universities.

Table 1

The annual (2005) overall research funding of these four universities ranges from 350 to 135 million Euro, whereof about 20 percent is private funding for the two older universities and around 17 percent for the two younger (Table 2). Private contractual research is smallest at Umeå University (1,5 percent of the total research revenue) and most pronounced at Uppsala University (almost 4 percent). Remaining part of private funding is untied research resources. As measured in relation to numbers of professors the research funding is considerably more

\footnotetext{
${ }^{11}$ For a more detailed description of this process, see Acs and Braunerhjelm (2005).
} 
equally distributed between the four universities: Linköping University report least resources (about 510000 Euro) while Umeå University is most abundtly endowed per professor (704 000Euro). ${ }^{12}$

Table 2

Measuring the academic success of these universities is a highly intricate task. In terms of achieving the government's goal of producing a certain number of $\mathrm{PhD}$ students, they all seem to be on track (Högskoleverket 2006). However, that reveals little about quality. Looking at citation statistics (field normalized scores), Uppsala seems to be ahead of the other three universities who - by and large - are on par (Vetenskapsrådet 2006).

\section{Hypotheses}

The role of universities in regional development could be expected to show up in a correspondence between their research specialization and the industrial specialization of the regions in which they are located. First, universities should be instrumental to knowledge intensive industries as a supplier of skilled labor and in access to research facilities, generating externalities in terms of knowledge spillovers and academic entrepreneurship. Second, as discussed in theoretical survey, proximity seems to be important in order to exploit knowledge spillovers. Third, special attention will be paid to whether more recently established universities reveal a stronger correspondence to regional industrial specialization as compared to the older universities that are likely to have nurtured traditions over several centuries.

The regions that host the universities we are focusing on - Linköping University, Lund University, Umeå University and Uppsala University - are captured through a dummy

\footnotetext{
${ }^{12}$ Including funding for research and PhD students (Högskoleverket 2006).
} 
variable that is assigned the value of one if a local university exists (UNI-region). The universities differ in their research specialization (Table 1), and we expect these differences to show up in a diversified pattern of regional specialization. In particular, Umeå University and Uppsala University are expected to be positively correlated with regional specialization in the Drugs and medicine industry in their respective regions, whereas Linköping University should enhance specialization in the engineering industries, particularly the Office and computing industry. Research at Lund's University is quite evenly distributed between the medical and engineering faculties, implying that, a priori, it is difficult to assign any expected relationship to regional specialization.

The extent to which an industry is embedded in an environment conducive to production of certain goods, should augment firms' capacity to absorb and exploit localized knowledge. Data on embeddedness is difficult, if not impossible, to obtain. Here it is approximated by a variable that takes on the value of one if a region hosts one industry at the same level of aggregation (4-digit level) belonging to the same three-digit industry (EMBED); and a value of two if there is local presence of two industries belonging to the same classification, etc. This variable is denoted as EMBED and proximity to other industry with a similar specialization is expected to have a positive effect on regional specialization.

Turning to the control variables contained in the vector $\mathrm{Z}$ in equation 4 , the two dominant Swedish university regions are included, i.e. Stockholm and Gothenburg. These two regions each host several universities established between the mid $19^{\text {th }}$ century and the latter half of the $20^{\text {th }}$ century. Hence, they were established in the interim period between the foundations of the two pairs of universities that we have chosen to study. The sheer size and dominance of these two regions (the two largest in Sweden) motivates that they should be controlled for in the regressions, since they are likely to influence the estimations of the other co- 
efficients. ${ }^{13}$ The size of these control regions implies that they also have quite a diversified production structure, and therefore the expected influence of universities on regional specialization is more ambiguous.

In the productivity regressions the same variables are used as in the regional specialization variables. We also add in the average size of firms in the respective industry (SIZE), which is calculated as the number of employees in an industry divided by the number of establishments in the industry. It is expected to have a positive correlation with value added since it should capture internal economies of scale. In addition, it also indicates whether a region's productivity is dependent upon fewer but larger establishments, suggesting that regional specialization is associated with more capital-intensive production. Nevertheless, as we run the regressions for each industry, the omission of a capital-variable should not yield biased estimates.

Productivity may also be affected over time through learning and regional spillovers. Data on labor productivity are only available for 1996 and 1999; however, production in previous periods may still influence productivity. To control for this we utilize a variable that takes on a value between 0 and 7 depending on the number of times regions have hosted production (measured by employment) in a particular industry, during previous points of observations $(1975,1978,1981,1984,19987,1991,1993)$. If an industry had no production prior to 1993 , the variable attains a value of 0 , whereas, had there been production for all of these observations, the variable attains a value of 7. This effect is denoted LEARN and we expect it to be positively related to productivity.

Finally, time specific effects are controlled for by implementing a time dummy (TDUM) that is given a value of one if the year is 1996 and zero if the year is 1999.

\footnotetext{
${ }^{13}$ The universities in Stockholm and Gothenburg, together with the four universities we are focusing on, comprise the major part of university research in Sweden.
} 
The variables are summarized in Table 3.

The data base

The regional impact of universities will be assessed by implementing data, acquired from Sweden Statistics, that are cross tabulated on regions and industries. The data cover the period 1975 to 1999 at three-year intervals. Data are sorted by year, region, industries and firm size, and include all observations, i.e., the entire population. The industries are classified according to the ISIC-system, and are available at the four-digit level for the years 1975 to 1993 . For the years 1996 and 1999 only three-digit data on manufacturing is available. The regional unit we will apply in the analysis is 70 labor market regions.

There are also some missing values in the database predominantly due to variables having a zero value for some observations. In other words, if there are no employees in a certain category, no figure is reported. However, the richness of the database and the relatively limited occurrence of missing values, means that the impact on the statistics should be negligible.

\section{Econometric model}

The influence of universities will be measured by regressing the presence of universities on regional specialization for a number of knowledge intensive industries, while controlling for other factors likely to influence regional specialization. Several regions do not host the knowledge intensive industries we will investigate, which motivates a censored dependent variable estimation technique. Even though the use of several different techniques is conceivable, we argue that Heckman's two-step procedure (Formby et al. 1986) is the appropriate 
method to capture the sequential production decision. ${ }^{14}$ The reason being that a region's specialization depends on a firms' decision where to locate or expand their production, having several options to choose between. More precisely, specialization can be seen as taking place in a sequential manner. First, choosing between all regions, firms decide where production (or expansion) should be located. Second, once the regional decision has been taken, production is influenced by a number of regional variables.

The model will be estimated for four separate industries (Drugs and medicines ISIC 3522, Office and computing machinery ISIC 3825, Professional and scientific instruments ISIC 3851, and a "control" industry Metal products ISIC 3813). The dependent variable used in the regressions is a specialization index defined as a region's relative share of employment within an industry. It is defined as employment of knowledge intensive industry $i$, located in region $j$ at time $t\left(\mathrm{IL}_{\mathrm{ijt}}\right)$, divided by the region's total employment $\left(\mathrm{TL}_{\mathrm{jt}}\right)$ in all industries, compared to the same measure at the aggregate (national) level; $\left(\frac{I L_{i j t}}{T L_{j t}}\right) /\left(\frac{I L_{i t}}{T L_{t}}\right)=R S P E C_{j t}$.

The variable RSPEC is characterized by a large number of zeroes, since there are numerous regions having no knowledge intensive production. The model to estimate is specified as:

\footnotetext{
${ }^{14}$ The Tobit method is a conceivable candidate. However, the estimates reflect both changes in the probability of being above the limit, and changes in the value of the dependent variable if already above the limit. A decomposition of the effects is possible (McDonald and Moffitt 1980), but the problem is that the two separate effects will always have the same sign and significance. In the present case it may well be that the probability effects and the marginal effects differ. Alternatively, since the location choice of firms is multinomial by nature, one way of accounting for this would be to estimate a multinomial logit or probit. However, the multinomial logit relies on a very strong assumption, the independence of irrelative alternatives, and the multinomial probit involves the evaluation of multiple integrals, something that is not feasible if the choice alternatives exceed three or four. Given these limitations, we believe that the best model to use is Heckman's two-stage estimation technique
} 


$$
R S P E C^{*}=\beta_{0}+Z^{\prime} \beta_{1}+\varepsilon_{i j t}
$$

where

$$
R S P E C= \begin{cases}\text {RSPEC }^{*} & \text { if } \quad \text { RSPEC }^{*}>0 \\ 0 & \text { if } \quad \text { RSPEC }^{*} \leq 0\end{cases}
$$

The residuals are assumed to have the properties $\varepsilon \sim \mathrm{N}\left(0, \sigma_{\varepsilon}{ }^{2}\right), \mathrm{E}\left(\varepsilon_{\mathrm{hjt}} \varepsilon_{\mathrm{ijt}}\right)=0$ for $h \neq i$, $\mathrm{E}\left(\varepsilon_{\mathrm{ijt}} \varepsilon_{\mathrm{ikt}}\right)=0$ for $j \neq k$ but $\mathrm{E}\left(\varepsilon_{\mathrm{ijs}} \varepsilon_{\mathrm{ijt}}\right) \neq 0$ for $s \neq t$.

The Heckman method implies that initially a probit function is estimated for all observations, i.e., both $\mathrm{RSPEC}>0$ and $\mathrm{RSPEC}=0$ are included in the regressions in order to obtain the probability effects,

$$
\mathrm{F}^{-1}\left(\operatorname{Pr}(\mathrm{Y})_{\mathrm{ijt}}\right)=\mathrm{J}_{\mathrm{ijt}}=\alpha_{0}+\mathrm{Z}^{\prime} \alpha_{1}
$$

where $\mathrm{F}^{-1}$ is the inverse of the cumulative standard normal distribution and $\mathrm{Y}$ takes the value of one if $\mathrm{RSPEC}>0$, and zero if $\mathrm{RSPEC}=0$. In expression $2, \operatorname{Pr}(\mathrm{Y})_{\mathrm{ijt}}$ represents the probability that industry $i$ have production in region $j$ at time $t$, given the values of the explanatory variables. The $\alpha$ 's are parameters showing the influence of the independent variables on the probability that the firm locates production in a certain country. From these estimates, a sample selection correction variable $\lambda$ - Heckman's lambda - is computed for all observations, 


$$
\lambda_{i j t}=\frac{f\left(-J_{i j t}\right)}{1-F\left(-J_{i j t}\right)}
$$

where $\mathrm{f}$ and $\mathrm{F}$ are the density and the cumulative standard normal distribution function, respectively. Then, the sample is restricted to observations for which RSPEC $>0$, and a standard OLS regression is run, in which the estimated correction variable, $\lambda$, is included:

$$
\operatorname{RSPEC}_{j, t}=\gamma_{0}+Z^{\prime} \gamma_{1}+\gamma_{2} \tilde{\lambda}_{i j t}+v_{i j t}
$$

The residuals are assumed to have the properties $v \sim \mathrm{N}\left(0, \sigma_{\mathrm{v}}{ }^{2}\right), \mathrm{E}\left(\mathrm{v}_{\mathrm{hjt}} \mathrm{v}_{\mathrm{ijt}}\right)=0$ for $h \neq i$, $\mathrm{E}\left(\mathrm{v}_{\mathrm{ijt}} \mathrm{V}_{\mathrm{ikt}}\right)=0$ for $j \neq k$ but $\mathrm{E}\left(\mathrm{v}_{\mathrm{ijs}} \mathrm{v}_{\mathrm{ijt}}\right) \neq 0$ for $s \neq t .{ }^{15}$

Since Heckman's lambda is included, the OLS equation will yield consistent parameter estimates. However, the estimated standard errors will be inefficient as we use the estimated, rather than the actual, value of $\lambda$. A White (1980) correction for heteroscedasticity is therefore required in order to obtain efficient standard errors of the estimated parameters. ${ }^{16}$

At the four-digit level the regressions stretch from 1975 to 1993, while regressions over the full period (1975-1999) can only be implemented using data at the three-digit level. At this level of aggregation the industries are present in most regions, hence, we will also report OLS-estimation results. Finally, we will also regress the presence of universities

\footnotetext{
${ }^{15}$ It should be noted that the probit and corrected Heckman OLS equations include the same explanatory variables in vector $Z$. A possible practical problem is then multicollinearity between $Z$ and $\lambda$. There is no theoretical basis that such problems must arise, however, since the latter variable is a non-linear combination of $\mathrm{Z}$, while OLS is a linear estimation technique.

${ }^{16}$ Standard properties are assumed to prevail with regard to the error term.
} 
on regional labor-productivity for the industries mentioned above. In this case data is even further restricted and the analysis will be limited to the period 1996 to 1999.

\section{Results}

We ran the regressions for three knowledge-intensive industries - Drugs and medicines, Office and computing machinery and Professional and scientific instruments - and a less knowledge intensive "control" industry (Metal products). Starting with the 4-digit level for the period 1975-1993, table 4a shows a positive and highly significant impact on the probability of regional specialization in pharmaceutical production where universities are strong in medical research. Note also that Linköping University, being specialized in engineering research, is shown to have no influence on regional specialization in Drugs and medicines. Also embeddedness (EMBED) displays a positive influence on the probability of regional specialization in the pharmaceutical industry. Note that there are obvious differences regarding the regional influence of universities, as shown in the Heckman OLS regressions. The presence of Uppsala University has a robust positive impact on the surrounding region's specialization, while Umeå University is shown to have a negative effect and the influence of Lund University is insignificant. We interpret this as being related to the embeddedness of the industry.

\section{Table 4a}

The statistical diagnostics support the choice of model, both with regard to Chi square statistics (high probability that the independent variables are significant) and independence statistics (the probability that the selection regression and the "main regression" are independent from one another). The number of observations where the dependent variable is zero, 
amounts to 373 . We also show, for comparability reasons, the OLS regression results that do deviate considerably from the Heckman estimations in several cases.

In the Office and computer industry a similar pattern emerges (Table 4B). The probability that regions hosting universities strong in engineering research are also specialized in Office and computer industry is confirmed as shown by the positive and strongly significant coefficient for Linköping University and Lund University. Again embeddedness is shown to be positively associated with the probability of regional specialization in Office and computing industry. In the second step, the Heckman OLS-regression supports the positive effect of the presence of Linköping University, but not in the case of Lund University. This probably reflects the more diversified research going on in Lund University.

\section{Table $4 b$}

The choice of method does not attain a similar strong support in the case of Office and computing machinery as indicated by the independence statistics, which are not as strongly significant as in the regressions on the Drug and medicine industry. Turning to OLS does not dramatically change the results; the positive effect of Linköping University remains, whereas Lund University fails to reach significance. Both Umeå University and Uppsala university are shown to have a negative effect on specialization in the Office and computer industry.

In the third knowledge intensive industry considered, i.e. Professional instruments, out of the four universities examined, only Lund fails to reach significance (Table 3c). This industry is closely connected to both the Pharmaceutical and the Office and computer industries and there is no obvious reason why Lund University has no impact. It could possibly be related to differences in specialization between the regions, a considerable share of the Professional instruments industry is part of traditional industrial production. Only in the case of 
Uppsala is the positive probability impact matched by a positive effect in regions undertaking production in this industry. The influence of the other universities varies from insignificant to negatively significant. One reason for these rather ambiguous results may be the relatively small size of this industry; about 13000 employees in 1993. The kind of complementarities and spillovers between the pharmaceutical and instrument industries may appear in a rather inadvertent manner. Note also that for this industry, embeddedness is not significant.

Table 4c

Finally, we ran an OLS-regression on the impact of the universities on a less researchintensive industry, Metal products (Table 4d). A positive effect is only attained for Linköping University; the interpretation being that this University is located in one of the industrial cores of Sweden, and that part of the specialization in industries related to engineering spills over to Metal products.

Table 4d

Considering the entire period, 1975 to 1999 , we have to resort to more aggregated data at the three-digit level, which means that most regions will actually host some production of the particular industry. The test statistics reject the two-step Heckman method and therefore OLS-techniques are implemented in the remaining regressions. The results are shown in Table 5. In the pharmaceutical industry the results are very similar to those obtained at the four-digit level; the significant differences being that Umeå University is now shown to have a negative and significant impact, while embeddedness does not display any effect on regional specialization. At this level of aggregation the latter variable becomes quite general and its relevance 
for the particular industry less obvious. In the Office and computer industry, the resultant sign of Linköping University changes from significantly positive to weakly negative. This suggests that even though positive effects may accrue from the university on regional specialization, they appear at a more specialized (disaggregated) level. In the instrument industry the results are basically the same for the four universities considered. Finally, in the "control" industry, Metal products, all universities are shown to have a negative and significant effect, indicating that to some extent universities "crowd out" simpler production. The low squared R-values are not too alarming, considering the high values of the F-statistics and that this is a crosssectional analysis.

Table 5

The last Table 6 contains the results for the labor productivity regressions, also undertaken at the three-digit level, since data are constrained to 1996 and 1999. In the Drugs and medicine industry the negative effect of Umeå University deviates markedly from the other two universities (Lund and Uppsala) that also have a pronounced specialization in medical research. The learning variable does not attain significance, while size and embeddedness display weak positive productivity effects. The latter signals some type of inter-industry spillovers, and it is also the only industry in which the effects of embeddedness gain some support.

In the Office and computer industry, Linköping University, as expected, is shown to positively affect productivity together with, and rather surprisingly, Umeå University. The other two universities we scrutinized display no such effects. The learning variable is not included as all regions had production in all the time periods. Turning to the Professional instrument industry, all universities specializing in medical research are reported to have posi- 
tively influenced productivity, which relates to the complementarities between medical research and instruments often used in the pharmaceutical sector. Note that the learning variable is shown to be strongly positive in this industry, being more production oriented than the research oriented pharmaceutical industry, where no such effects were discerned. Also firm size has a significant impact on productivity. For our control industry, Metal products, none of the universities is shown to have a positive impact on productivity, rather the opposite prevails. Instead, size seems to be the dominant factor of higher labor productivity.

Table 6

Again, the relatively low squared R-values, albeit considerably higher then in the previous regressions, should not be a cause of concern, considering that this is a cross-section analysis. Moreover, the F-statistics are at a highly satisfactorily level. Even though the analysis basically supports the results obtained at a finer level of aggregation, overall the interpretation of the results becomes harder as we insert broader measures of industries.

\section{Summarizing the results}

The regressions show that at a more disaggregated level the probability of a knowledgeintensive being located in a particular region is increasing in presence of a university being specialized in that particular knowledge/research field. This is particularly clear for the Drugs and medicines industry, but also holds for the Office and computing industry. When it comes to the Professional instrument industry, where the associated research area is less evident, there seems to be a stronger relationship with universities specialized in the medical fields. Turning to the regional effects in terms of production and specialization, the results differ widely between universities: while Uppsala University seems to exert a strong positive impact 
on regional specialization in the Drugs and medicines industry, the results is reversed for Umeå University. Similarly, the Office and computing industry is positively correlated with Linköping University, but no significant relationship was obtained for Lund University. The interpretation is that the impact of universities on regional specialization is related to the commercial environment in which the universities are embedded.

When the same analysis is undertaken at a higher level of aggregation level (and extended in time), the results are basically corroborated for the Drugs and medicines, the Professional instrument and the Metal product industries. However, in the Office and computing machinery industry, a different picture emerges where Linköping University attains a weakly significant and negative value. We confer the explanation to a much more pervasive technology used in the Office and computing machinery industry, which also affect other industries, i.e. the level of aggregation is likely to conceal the effect of Linköping University to one particular industry. Finally, when we address the issue of productivity we discern obvious differences in the Drugs and medicines industry as regards the impact of universities on regional productivity. For instance, a negative impact is reported for Umeå University while Uppsala University is shown to have a positive impact. In the remaining industries the results comply well with the previously reported relationships between regional performance and university performance. Size of the establishments appears as an important explanatory variable of regional productivity.

\section{The role of new universities in regional development}

Are new universities the appropriate tool to orchestrate a regional transformation towards new and more knowledge intensive industries? The empirical analysis suggests that the universities have a potentially important role to play in regional development, perhaps even decisive, but also that a successful re-orientation of the commercial sector hinges on a number of other 
factors. Moreover, the role of universities do not seem to primarily be determined by the age of universities. This suggests that the way they are organized, incentive structures and their capacity to establish external links also are likely to be vital components in order for universities to become regional growth nodes.

The environment in which the universities are embedded seems to be one decisive factor for a successful interaction and collaboration with the commercial sector. Linköping University in particular illustrates this point. It is located in one of the traditional Swedish industrial sites, which over the last few decades have specialized in aerospace, telecommunication and similar high-technology production. This also applies to Lund University in the southern part of Sweden, where former manufacturing industries such as shipyards, basic food production and textile have been substituted by pharmaceutical, functional food and, to some extent, engineering production. In the Uppsala region the universities cooperation with the pharmaceutical industry goes a long way back, even though more recently the large firms partly has been replaced by a biomedical/biotechnology small firm dominated cluster. Thus, there are reasons to believe that regional development (specialization and productivity) has been characterized by interdependency and two way communication flows between academia and the commercial sector.

The environment surrounding Umeå University contrasts starkly with that of the other universities; the industrial tradition is weak, production has been orientated towards resource intensive production and the entrepreneurial spirit has, by and large, been absent. Thus, even though the overall institutional set-up is basically identical within the four regions in terms of regulations, taxes, etc., the outcome differs. 


\section{Conclusions}

The presence of a university is not, in itself, enough to spur regional commercialization and development. Nor does the age of the university seem to be of pivotal importance. Without the proper environment, benign attitude and norms towards interaction with the private sector, regional restructuring is less likely to occur. This partly corroborates conclusions drawn in other studies (Clarke 1998; Feldman and Desrochers 2001; Siegel et al. 2003a, 2003b), but does also provide new insights into the interplay between the regional setting and universities. Moreover, this paper stresses the importance of a deeper understanding of the mechanisms that diffuse and convert knowledge into useful goods and services. A too simplistic modeling of such mechanisms runs the risk of resulting in sub-optimal normative conclusions.

Obviously, the conditions for increasing commercialization and interaction with industry are not only shaped by the universities, but are rather a combination of policies at the national, regional and university level. Thus, the challenge policy-makers at the regional and national levels are to provide the appropriate institutions and prerequisites to enable academic knowledge to be converted into commercially viable products and services. To obtain full leverage of such policy it should be matched by universities that are organized to facilitate external links and commercialization of academic research.

To identify the exact channels of knowledge transfers, cross-fertilization and feedbacks between the commercial sector and the universities is beyond the scope of this paper. To excavate more deeply into these mechanisms seems an important task for future research. 
TABLE 1: NUMBER OF TEACHING AND RESEARCH STAFF (FULL TIME EQUIVALENT) BY UNIVERSITY AND NATIONAL RESEARCH SUBJECT AREA

\begin{tabular}{|l|ll|ll|ll|ll|}
\hline University/ & \multicolumn{2}{|l|}{ Linköping } & Lund & & Umeå & & Uppsala & \\
Faculty & Number & Percent & Number & Percent & Number & Percent & Number & Percent \\
\hline Medical & 447 & 22 & 771 & 20 & 727 & 32 & 783 & 24 \\
Engineering & 703 & 35 & 963 & 25 & 133 & 6 & 164 & 5 \\
\hline
\end{tabular}

Source: Statistics Sweden

TABLE 2. TOTAL RESEARCH FUNDING (INCLUDING PH D STUDENTS, MILLIONS EURO, 2005) AND CITATIONS (AVERAGE 1998-2002, FIELD NORMALIZED SCORES) BY UNIVERSITY

\begin{tabular}{|l|l|l|l|l|}
\hline University & Linköping & Lund & Umeå & Uppsala \\
\hline Research fund- & 136 & 357 & 171 & 300 \\
ing, total & & & & \\
\hline Citations & 1.07 & 1.08 & 1.09 & 1.12 \\
\hline
\end{tabular}

Source: Högskoleverket (2006), Vetenskapsrådet (2006) 
TABLE 3. DEFINITIONS AND EXPECTED SIGNS OF THE EXPLANATORY

VARIABLES

\begin{tabular}{|c|c|c|}
\hline Variable & Definition & $\begin{array}{l}\text { Expected effect on } \\
\text { value added }\end{array}$ \\
\hline University region (UNI-region) & $\begin{array}{l}\text { Takes on the value of } 1 \text { if a regional univer- } \\
\text { sity exists, otherwise } 0 .\end{array}$ & + \\
\hline Embeddedness (EMBED) & $\begin{array}{l}\text { Takes on a value of } 1 \text { if there exists another } \\
4 \text { (3)-digit industry belonging to the same } \\
\text { group at the } 3(2) \text {-digit level of classifica- } \\
\text { tion, } 2 \text { if two industries exist, etc. }\end{array}$ & + \\
\hline Learning (LEARN) & $\begin{array}{l}\text { Takes on a value of } 1 \text { if the industry existed } \\
\text { in the region in a previous period, } 2 \text { if the } \\
\text { industry existed in the region at two previ- } \\
\text { ous observations, etc. }\end{array}$ & + \\
\hline Average size (SIZE) & $\begin{array}{l}\text { The average size of firms in one industry } \\
\text { and region. Calculated as the number of } \\
\text { employees divided by the number of firms. }\end{array}$ & + \\
\hline Dummy for (TDUM) & $\begin{array}{l}\text { Takes on the value of } 1 \text { if the observation } \\
\text { refers to } 1996 \text {, otherwise } 0 .\end{array}$ & $+/-$ \\
\hline
\end{tabular}


TABLE 4a. REGRESSION RESULTS FOR DRUGS AND MEDICINES. HECKMAN TWO-STEP MODEL AND OLS. DEPENDENT VARIABLE: PRESENCE OF INDUSTRY IN REGIONS AND REGIONAL SPECIALIZATION.

(FOUR DIGIT INDUSTRY LEVEL, 1975 - 1993.)

\begin{tabular}{|c|c|c|c|}
\hline & $\begin{array}{l}\text { Heckman } \\
\text { Probit } \\
\mathrm{Y}=\text { existence }\end{array}$ & $\begin{array}{l}\text { Heckman OLS } \\
\mathrm{Y}=\text { Regional } \\
\text { specialization }\end{array}$ & $\begin{array}{l}\text { OLS } \\
\mathrm{Y}=\text { Regional } \\
\text { specialization }\end{array}$ \\
\hline UNI- & .39 & $-1.55 * * *$ & $-.49 * *$ \\
\hline Linköping & $(.93)$ & $(-2.74)$ & $(-2.32)$ \\
\hline \multirow[t]{2}{*}{ UNI-Umeå } & $5.19 * * *$ & $-1.71 * * *$ & $.30^{*}$ \\
\hline & $(4.23)$ & $(-2.62)$ & $(1.96)$ \\
\hline \multirow[t]{2}{*}{ UNI-Lund } & $3.34 * * *$ & -.79 & .60 \\
\hline & $(2.75)$ & $(-1.21)$ & $(1.62)$ \\
\hline UNI- & $7.80 * * *$ & $7.72 * * *$ & $9.91 * * *$ \\
\hline Uppsala & $(5.87)$ & $(3.62)$ & $(5.78)$ \\
\hline \multirow[t]{2}{*}{ Gothenburg } & 1.29 & $-2.33 * * *$ & $-.93 * * *$ \\
\hline & $(.99)$ & $(-3.66)$ & $(-2.72)$ \\
\hline \multirow{2}{*}{ Stockholm } & -2.30 & -.04 & $1.35 * * *$ \\
\hline & $(-1.26)$ & $(-.07)$ & (3.64) \\
\hline \multirow[t]{2}{*}{ EMBED } & $.85 * * *$ & .02 & $.41^{*}$ \\
\hline & $(2.85)$ & $(.16)$ & $(1.80)$ \\
\hline$\Lambda$ & & -1.45 & \\
\hline \multirow[t]{2}{*}{ Constant } & $-2.18 * * *$ & $2.58 * * *$ & -.00 \\
\hline & $(-7.59)$ & $(3.63)$ & $(-.01)$ \\
\hline Wald-Reg & & 442.71 & \\
\hline $\mathrm{P}>\operatorname{chi} 2$ & & .00 & \\
\hline$P$ indep & & .00 & \\
\hline $\mathrm{R}^{2}$ & & & .73 \\
\hline $\mathrm{F}$ & & & 58.50 \\
\hline No. of obs. & 490 & 117 & 117 \\
\hline Left cens. & 373 & - & - \\
\hline
\end{tabular}


TABLE 4B. REGRESSION RESULTS FOR OFFICE AND COMPUTING MACHINERY. HECKMAN TWO-STEP MODEL AND OLS. DEPENDENT VARIABLE: PRESENCE OF INDUSTRY IN REGIONS AND REGIONAL SPECIALIZATION.

(FOUR DIGIT INDUSTRY LEVEL, 1975 - 1993.)

\begin{tabular}{|c|c|c|c|}
\hline & $\begin{array}{l}\text { Heckman } \\
\text { Probit } \\
\text { Y=existence }\end{array}$ & $\begin{array}{l}\text { Heckman OLS } \\
\text { Y=Regional } \\
\text { specialization }\end{array}$ & $\begin{array}{l}\text { OLS } \\
\text { Y=Regional } \\
\text { specialization }\end{array}$ \\
\hline$\overline{\text { UNI- }}$ & $8.17^{* * *}$ & $6.85^{* * *}$ & $6.87^{* * *}$ \\
\hline Linköping & (86.88) & $(8.23)$ & $(8.14)$ \\
\hline \multirow[t]{2}{*}{ UNI-Umeå } & $-.86^{*}$ & $-.68^{* * *}$ & $-.71 * * *$ \\
\hline & $(-1.76)$ & $(-4.03)$ & $(-4.05)$ \\
\hline \multirow[t]{2}{*}{ UNI-Lund } & $8.41^{* * *}$ & .59 & .62 \\
\hline & (91.35) & $(1.43)$ & $(1.47)$ \\
\hline UNI- & -.07 & $-.56 * * *$ & $-.56^{* * *}$ \\
\hline Uppsala & $(-.16)$ & $(3.95)$ & $(-3.94)$ \\
\hline \multirow[t]{2}{*}{ Gothenburg } & $8.83^{* * *}$ & $-.46^{* *}$ & $-.44 * *$ \\
\hline & (79.19) & $(-2.26)$ & $(-2.18)$ \\
\hline \multirow[t]{2}{*}{ Stockholm } & $8.68^{* * *}$ & $1.46^{* * *}$ & $1.49^{* * *}$ \\
\hline & $(87.58)$ & $(8.07)$ & $(8.36)$ \\
\hline \multirow[t]{2}{*}{ EMBED } & $.35^{* * *}$ & -.06 & -.05 \\
\hline & $(4.86)$ & $(-.56)$ & $(-.45)$ \\
\hline$\Lambda$ & & -.05 & \\
\hline \multirow[t]{2}{*}{ Constant } & $-.95 * * *$ & $1.05 * * *$ & $.98^{* *}$ \\
\hline & $(-3.81)$ & $(2.59)$ & $(2.34)$ \\
\hline Wald-Reg & & 679.62 & \\
\hline $\mathrm{P}>$ chi2 & & .00 & \\
\hline $\mathrm{P}$ indep & & .11 & \\
\hline $\mathrm{R}^{2}$ & & & .25 \\
\hline $\mathrm{F}$ & & & 115.25 \\
\hline No. of obs. & 490 & 302 & 302 \\
\hline Left cens. & 188 & - & - \\
\hline
\end{tabular}


TABLE 4C. REGRESSION RESULTS FOR PROFESSIONAL INSTRUMENTS. HECKMAN TWO-STEP MODEL AND OLS. DEPENDENT VARIABLE: PRESENCE OF INDUSTRY IN REGIONS AND REGIONAL SPECIALIZATION.

(FOUR DIGIT INDUSTRY LEVEL, 1975 - 1993.)

\begin{tabular}{|c|c|c|c|}
\hline & $\begin{array}{l}\text { Heckman } \\
\text { Probit } \\
\mathrm{Y}=\text { existence }\end{array}$ & $\begin{array}{l}\text { Heckman } \\
Y=\text { Regional } \\
\text { specialization }\end{array}$ & $\begin{array}{l}\text { OLS } \\
Y=\text { Regional } \\
\text { specialization }\end{array}$ \\
\hline UNI- & $5.25 * * *$ & $-.60 * * *$ & $-.53 * * *$ \\
\hline Linköping & $(18.65)$ & $(-6.52)$ & $(-7.15)$ \\
\hline \multirow[t]{2}{*}{ UNI-Umeå } & $5.94 * * *$ & .41 & $.48^{*}$ \\
\hline & (27.33) & $(1.45)$ & $(1.73)$ \\
\hline \multirow{2}{*}{ UNI-Lund } & .90 & $.71 * *$ & $.74 * *$ \\
\hline & $(1.01)$ & $(2.49)$ & $(2.60)$ \\
\hline UNI- & $5.76^{* * *}$ & .10 & .13 \\
\hline Uppsala & $(23.12)$ & $(.45)$ & $(.59)$ \\
\hline \multirow{2}{*}{ Gothenburg } & $-4.04 * *$ & $-.51 * * *$ & $-.46 * * *$ \\
\hline & $(-2.50)$ & $(-3.20)$ & $(-2.92)$ \\
\hline \multirow[t]{2}{*}{ Stockholm } & $-13.29 * * *$ & $1.09 * * *$ & $1.12 * * *$ \\
\hline & $(-4.44)$ & $(3.67)$ & $(3.73)$ \\
\hline \multirow[t]{2}{*}{ EMBED } & .08 & .14 & .16 \\
\hline & $(.56)$ & $(1.15)$ & $(1.36)$ \\
\hline$\Lambda$ & & -.18 & \\
\hline \multirow[t]{2}{*}{ Constant } & $-.36^{* *}$ & $.75 * * *$ & $.67 * * *$ \\
\hline & $(-2.55)$ & $(8.46)$ & $(10.32)$ \\
\hline Wald-Reg & & 256.04 & \\
\hline $\mathrm{P}>\operatorname{chi} 2$ & & .00 & \\
\hline $\mathrm{P}$ indep & & .09 & \\
\hline $\mathrm{R}^{2}$ & & & .07 \\
\hline $\mathrm{F}$ & & & 35.11 \\
\hline No. of obs. & 490 & 369 & 369 \\
\hline Left cens. & 121 & - & - \\
\hline
\end{tabular}

Note: t-statistics in parentheses. ${ }^{*}, * *$ and $* * *$ denote the significance at the 10,5 and 1 percent level, respectively. 
TABLE 4D. REGRESSION RESULTS FOR METAL PRODUCTS. OLS, DEPENDENT VARIABLE REGIONAL SPECIALIZATION.

(FOUR DIGIT INDUSTRY LEVEL, 1975 - 1993.)

OLS

$\mathrm{Y}=$ Regional

\begin{tabular}{ll} 
& specialization \\
\hline UNI- & $.49^{* * *}$
\end{tabular}

Linköping (2.35)

UNI-Umeå $\quad-.76^{* * *}$

$(-14.72)$

UNI-Lund $\quad-.48 * * *$

$(-5.96)$

UNI- $\quad-.69 * * *$

Uppsala $\quad(-10.18)$

Gothenburg -.06

$(-1.02)$

Stockholm $\quad-.67 * * *$

$(-10.71)$

EMBED $\quad-.15$

$(-1.62)$

Constant $1.66^{* * *}$

(6.23)

$\mathrm{R}^{2} \quad .06$

F $\quad 51.39$

No. of obs. 490

Note: t-statistics in parentheses. ${ }^{*}, * *$ and $* * *$ denote the significance at the 10,5 and 1 percent level, respectively. 
TABLE 5. REGRESSION RESULTS, OLS.

DRUGS AND MEDICINES (1), OFFICE AND COMPUTING MACHINERY (2), PROFESSIONAL INSTRUMENTS (3), AND METAL PRODUCTS (4).

DEPENDENT VARIABLE: REGIONAL SPECIALIZATION (THREE DIGIT INDUSTRY LEVEL, 1975 - 1999.)

\begin{tabular}{lllll}
\hline & $(1)$ & $(2)$ & $(3)$ & $(4)$ \\
\hline UNI- & $-.46^{* * *}$ & $-.21^{*}$ & $-.46^{* * *}$ & $-.54^{* * *}$ \\
Linköping & $(-3.40)$ & $(-1.69)$ & $(-7.10)$ & $(-5.18)$ \\
UNI-Umeå & $-.36^{* *}$ & $-.66^{* * *}$ & .17 & $-1.03^{* * *}$ \\
& $(-2.40)$ & $(-10.45)$ & $(.83)$ & $(-20.56)$ \\
UNI-Lund & $1.06^{* * *}$ & $-.34^{* * *}$ & $1.02^{* * *}$ & $-.68^{* * *}$ \\
& $(6.05)$ & $(-5.55)$ & $(5.93)$ & $(-11.48)$ \\
UNI- & $3.31^{* * *}$ & $-1.06^{* * *}$ & $.74^{* * *}$ & $-.37^{* *}$ \\
Uppsala & $(5.20)$ & $(-14.49)$ & $(7.18)$ & $(-2.18)$ \\
Gothenburg & -.14 & $-.35^{* * *}$ & $.50^{* *}$ & $-.55^{* * *}$ \\
& $(-.87)$ & $(-6.48)$ & $(2.49)$ & $(-9.48)$ \\
Stockholm & $.99^{* * *}$ & $-.66^{* * *}$ & $1.37^{* * *}$ & $-.97^{* * *}$ \\
& $(5.05)$ & $(8.73)$ & $(7.05)$ & $(-15.64)$ \\
EMBED & -.17 & -.00 & $.50^{* * *}$ & $-.31^{* *}$ \\
& $(-1.02)$ & $(-.00)$ & $(7.87)$ & $(-2.19)$ \\
Constant & $1.41^{* * *}$ & $1.31^{* *}$ & $-1.40^{* * *}$ & $2.67^{* * *}$ \\
& $(2.62)$ & $(2.40)$ & $(-6.53)$ & $(4.73)$ \\
\hline R ${ }^{2}$ & .04 & .03 & .05 & .06 \\
F & 58.37 & 43.65 & 55.63 & 77.86 \\
No. of obs. & 551 & 630 & 554 & 630
\end{tabular}

Note: t-statistics in parentheses. ${ }^{*}{ }^{* *}$ and ${ }^{* * *}$ denote the significance at the 10,5 and 1 percent level, respectively. 
TABLE 6. REGRESSION RESULTS, OLS.

DRUGS AND MEDICINES (1), OFFICE AND COMPUTING MACHINERY (2), PROFESSIONAL INSTRUMENTS (3), AND METAL PRODUCTS (4).

DEPENDENT VARIABLE: LABOR PRODUCTIVITY (THREE DIGIT INDUSTRY LEVEL, 1975 - 1999.)

\begin{tabular}{|c|c|c|c|c|}
\hline & (1) & (2) & (3) & (4) \\
\hline UNI- & $-.20 * *$ & $.02 * *$ & -.06 & $-.06^{* * *}$ \\
\hline Linköping & $(-2.11)$ & (2.10) & $(-.66)$ & $(-3.65)$ \\
\hline \multirow[t]{2}{*}{ UNI-Umeå } & $-.17 * * *$ & $.10 * * *$ & $.22 * *$ & -.01 \\
\hline & $(-3.44)$ & (5.47) & (2.39) & $(-.45)$ \\
\hline \multirow[t]{2}{*}{ UNI-Lund } & $.20 * * *$ & -.10 & $.13 * *$ & -.01 \\
\hline & (4.33) & $(-8.59)$ & $(2.53)$ & (-.69) \\
\hline UNI- & .33 & -.04 & $.05^{*}$ & -.02 \\
\hline Uppsala & (.99) & $(-.59)$ & $(1.77)$ & $(-1.15)$ \\
\hline \multirow[t]{2}{*}{ Gothenburg } & -.06 & $.07 * * *$ & $.13 * * *$ & -.01 \\
\hline & $(-.99)$ & (5.94) & (3.66) & $(-.96)$ \\
\hline \multirow[t]{2}{*}{ Stockholm } & -.07 & $.14 * * *$ & $.21 * * *$ & $.06 * * *$ \\
\hline & $(-1.33)$ & (5.73) & (7.33) & $(6.99)$ \\
\hline \multirow[t]{2}{*}{ EMBED } & $.12^{*}$ & .01 & -.17 & .02 \\
\hline & (1.73) & $(.57)$ & $(-1.07)$ & $(1.35)$ \\
\hline \multirow[t]{2}{*}{ LEARN } & .03 & & $.05 * * *$ & \\
\hline & (1.18) & & $(2.90)$ & \\
\hline \multirow[t]{2}{*}{ SIZE } & $.17^{*}$ & $.24 * *$ & $.45^{* * *}$ & $.82 * * *$ \\
\hline & $(1.66)$ & $(2.44)$ & (4.63) & $(5.11)$ \\
\hline \multirow[t]{2}{*}{ Tdum } & $.10^{*}$ & .02 & .03 & $.03 * * *$ \\
\hline & $(1.83)$ & $(.90)$ & $(.90)$ & $(2.91)$ \\
\hline \multirow[t]{2}{*}{ Constant } & -.24 & $.29 * * *$ & .46 & $.18^{* * *}$ \\
\hline & $(-.78)$ & $(4.75)$ & $(.75)$ & $(3.00)$ \\
\hline$\overline{\mathrm{R}^{2}}$ & .24 & .13 & .26 & .28 \\
\hline $\mathrm{F}$ & 19.07 & 103.59 & 16.75 & 31.16 \\
\hline No. of obs. & 100 & 140 & 96 & 140 \\
\hline
\end{tabular}

Note: t-statistics in parentheses. ${ }^{*}{ }^{* *}$ and ${ }^{* * *}$ denote the significance at the 10,5 and 1 percent level, respectively. 
FIGURE 1a. NUMBER OF PERSONS IN RESPECTIVE REGION EMPLOYED IN DRUGS AND MEDICINES INDUSTRY, 1975-1993

\section{Employed in Pharmaceuticals}

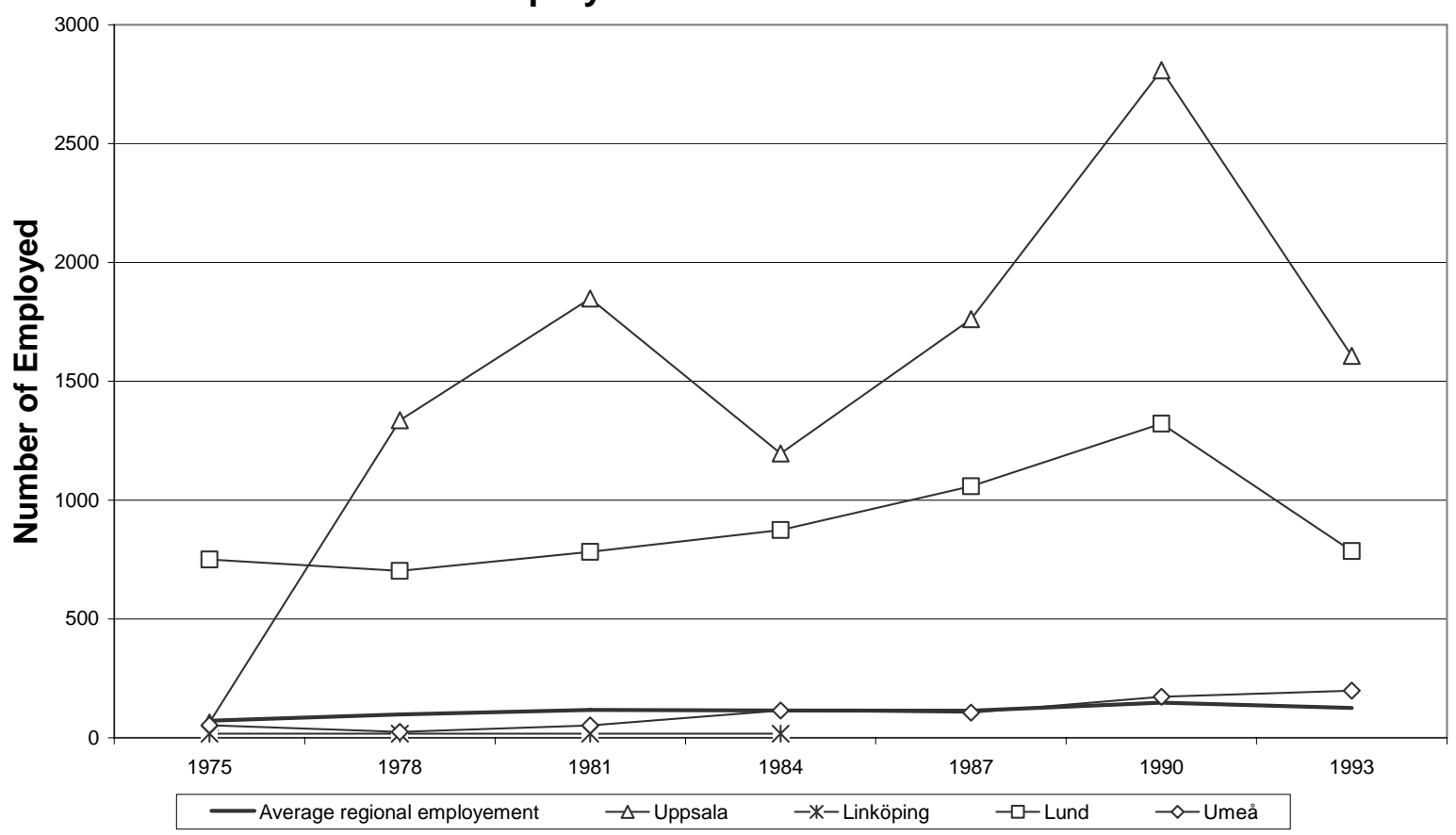

FIGURE 1b. NUMBER OF PERSONS IN RESPECTIVE REGION EMPLOYED IN OFFICE AND COMPUTING MACHINERY INDUSTRY (ICT), 1975-1993

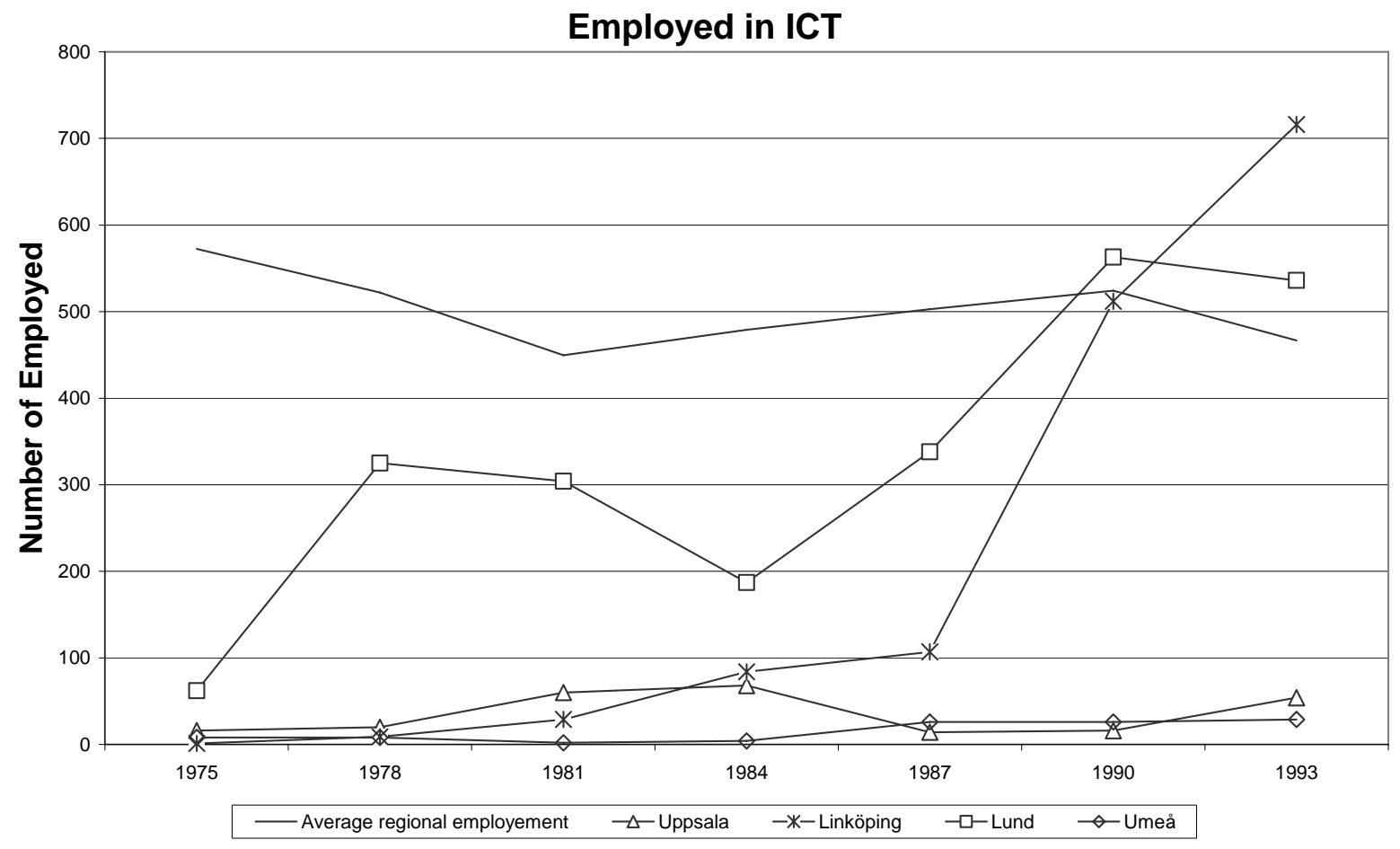




\section{References}

Acs, Z. and Braunerhjelm, P. 2005: The entrepreneurship-philanthropy nexus: Implication for internationalization, Management International Review, 45: 111-144.

Acs, Z., Audretsch, D. and Feldman, M. 1992: Real effects of academic research, American Economic Review, 82: 363-367.

Acs, Z., Audretsch, D., Braunerhjelm, P. and Carlsson, B. 2003: The missing link: The knowledge filter and endogenous growth, CEPR Discussion paper 4783, CEPR, London.

Aghion, P. and Howitt, P. 1992: A model of growth through creative destruction, Econometrica, 60: 323-351.

Aghion, P. and Howitt, P. 1998: Endogenous Growth Theory. Cambridge, MA: MIT Press

Aghion, P. and Griffith, R 2005: Competition and Growth: Reconciling Theory and Evidence. Cambridge, Ma: MIT Press.

Amin, A. and Thrift, N. 1994: Globalization, Institutions and Regional Development in Europe. Oxford: Oxford University Press

Andersson, R., Quigley, J. and Wilhelmsson, M. 2004: University decentralization as regional policy: the Swedish experiment, Journal of Economic Geography, 4: 371-388.

Anselin, L., Varga, A. and Acs, Z. 1997: Local geographic spillovers between university research and high technology innovation, Journal Of Urban Economics, 42: 422-448.

Anselin, L., Varga, A. and Acs, Z. 2000: Geographic spillovers and university research: A spatial econometric analysis, Growth\&Change, 31: 501-516.

Antonelli, C. 2007: The foundations of the economics of innovation: From the classical legacies to the economics of complexity, mimeo, University of Turin.

Armstrong, H., Darrel, J. and Grove-White, R. 1997: Maximizing the local economic, environmental and social benefits of a university: Lancaster University, GeoJournal, 41: $339-50$.

Arrow, K.J. 1962: The economic implications of learning by doing, Review of Economic Studies, 29: 155-173.

Arundel, A. and Geuna, A. 2004: Proximity and the use of public science by innovative European firms, Economics of Innovation and Technology, 13: 559-580.

Autio, E. and Yli-Renko, H. 1998: The network embeddedness of new technology-based firms: Developing a systemic evolutionary model, Small Business Economics, 11: 253-269. 
Azagra, C. and Llerena, P. 2003: Types of contractual funding and university patents: From analysis to case study, Conference on Knowledge and Economic and Social Change, Manchester.

Balconi, M. Breschi, S. and Lissoni, F. 2004: Networks of inventors and the role of academia: An exploration of Italian patent data, Research Policy, 33: 127-145.

Bleaney, M., Binks, M., Greenaway, D., Reed, G. and Whynes, D. 1992: What does a university add to its local economy?, Applied Economics, 24: 305-311.

Bercovitz, J. and Feldman, M. 2004: Academic entrepreneurs: Social learning and participation in university technology transfer, mimeo, University of Toronto.

Boucher, G., Conway, C. and van der Mer, E. 2003: Tiers of engagement by universities in their region's development, Regional Studies, 37: 887-897.

Braunerhjelm, P. and Feldman, M. 2006: Cluster genesis. Oxford: Oxford University Press.

Caloghirou, Y., Constantelou, A. and Vonortas, N.S. 2001: Knowledge Flows in European Industry: Mechanisms and Policy Implications. London: Routledge.

Caniels, M. 2000: Knowledge Spillovers and Economic Growth: Regional Growth Differentials Across Europe. Cheltenham and Northampton: Edward Elgar.

Castells, M. 1989: The3 Informational City. Information Technology, Economic Restructuring and the Urban-Regional Process. Oxford: Basil Blackwell.

Chesire, P. and Malecki, E. 2004: Growth, development, and innovation: A look backward and forward, Regional Science, 83: 249-267.

Clark, B.R. 1995: Places of Inquiry: Research and Advanced Education in Modern Universities. Berkeley and Los Angeles: University of California Press.

Clark, B.R. 1998: Creating Entrepreneurial Universities: Organizational Pathways of Transformation. New York: IAU Press.

Denison, E. 1968: Measuring the economic contribution of education and the 'residual' to economic growth, in Bowman, J. (ed.), Readings in the Economics of Education. Paris: Unesco.

Feldman, M. 1999: The new economics of innovation, spillovers and agglomeration: A review of empirical studies, The Economics of Innovation and New Technology, 8: 525.

Feldman, M. and Desrochers, P. 2001: Research universities and local economic development: Lessons from the history of the Johns Hopkins University, Industry and Innovation, 10: 5-25. 
Feller, I. 1990: Universities as engines of growth: They think they can, Research Policy, 19: $335-348$.

Felsenstein, D. 1996: The university in the Metropolitan arena: Impacts and public policy implications, Urban Studies, 33: 1565-1581.

Florax, R. 1992: The University: A Regional Booster?. Avebury: Aldershot.

Fontana, R., Geuna A. and Matt, M. 2003: Firm size and openness: The driving forces of university-industry collaboration, SPRU WPS No. 103, University of Sussex.

Formby, T., Hill, R. and Johnson, S. 1986: Advanced Econometric Methods. New York: Springer-Verlag.

Franklin, S., Wright, M. and Lockett, A. 2001: University technology transfer: Do incentives, management and location matter?, Journal of Technology Transfer, 28: 81-85.

Geuna, A. and Nesta, L. 2006: University patenting and its effect on academic research: The emerging European evidence, Research Policy, 35: 790-807.

Goldfarb, B. and Henrekson, M. 2003: Bottom-up vs. top-down: Towards the commercialization of university intellectual property, Research Policy, 32: 577-609.

Gulbrandsen, M. and Smeby, J.-C, 2005: The external orientation of university researchers and implications for academic performance and management, Research Policy, 34: 932-950.

Hall, B., Link, A. and Scott, J. 2000: Universities as research partners, NBER WP 7643, Cambridge, Ma.

Högskoleverket 2006: Universitet och högskolor, 2006:26 Annual Report, Stockholm: Högskoleverket.

Hotz-Hart, B. 2000: Innovation networks, Regions, and globalization, in Clark, G., Feldman, M. and Gertler, M. (eds.), The Oxford Handbook of Economic Geography. Oxford: Oxford University Press.

Jaffe, A., Trajtenberg, M. and Henderson, R. 1993: Geographic localization of knowledge spillovers as evidenced by patent citations, Quarterly Journal of Economics, 108: 577598.

Karlsson, C. and Zhang, W-B. 2001: The role of universities in regional development. endogenous human capital and growth in a two-region model, The Annals of Regional Science, 35: 179-197.

Keane, J. and Allison, J.,1999: The intersection of the learning region and local and regional economic development, Regional Studies, 33: 896-902. 
Kline, S. and Rosenberg, N. 1987: An overview of innovation, in Landau, R. and Rosenberg, N. (eds.), The Positive Sum Strategy. Washington: National Academy Press.

Link, A.N. 1996: Research joint ventures: Evidence from federal register filings, Review of Industrial Organization, 11: 617-628.

Lundvall, B.-Å. (ed.) 1992: National Systems of Innovation: Towards a Theory of Innovation and Interactive Learning. London: Pinter Publishers.

Lundvall, B.-Å. and Johnson, B. 1994: The learning economy, Journal Of Industry Economy, 2: $23-42$.

Mansfield, E. 1995: Academic research underlying industrial innovations: Sources, characteristics and financing, Review of Economics and Statistics, 77: 55-65.

Maskell, P. and Törnquist, G. 1999: Building a Cross-Border Learning Region: Emergence of the North European Öresund Region. Copenhagen: Copenhagen Business School.

McDonald, J. and Moffit, R. 1980: The use of Tobit analysis, The Review of Economics and Statistics, 62: 318-321.

Metcalfe, J.S., Foster, J. and Ramlogan, R. 2006: Adaptive economic growth, Cambridge Journal of Economics, 30: 7-32.

Meyer-Krahmer, F. and Schmoch, U. 1998: Science-based technologies: University-industry interactions in four fields, Research Policy, 27: 835-851.

Meyer, M. 2003, Academic patents as an indicator of useful research? A new approach to measure academic inventiveness, Research Evaluation, 24: 475-482.

Mohnen, P. and Hoareau, C. 2002: What type of enterprise forges close ties with universities and government labs? Evidence from CIS2, Merit-Infonomics Research Memorandum Series, August.

Mowery, D. and Sampat, B. 2001: University patent and patent policy debates in the USA, 1925-1980, Industrial and Corporate Change, 10: 781-814.

Mowery, D. and Ziedonis, A. 2001: Numbers, quality and entry: How has the Bayh-Dole Act affected U.S. Universities Patenting and Licensing, in Jaffe, A., Lerner, J. and Stern, S. (eds.), Innovation Policy and the Economy. Cambridge, Ma: MIT Press.

Mowery, D. and Ziedonis, A. 2002: Academic patent quality and quantity before and after the Bayh-Dole Act in the United States, Research Policy, 31: 399-418.

Mowery, D., Nelson, R., Sampat, B. and Ziedonis, A. 2001: The growth of patenting and licensing by U.S. universities: An assessment of the effects of the Bayh-Dole Act of 1980, Research Policy, 30: 99-119. 
Nelson, R. 2001: Observations on the post-Bayh-Dole rise of patenting at American universities, Journal of Technology Transfer, 26: 13-19.

Nelson, R. 2002: Bringing institutions into evolutionary growth theory, Journal of Evolutionary Economics, 12: 61-74.

Nelson, R. and Winter, S. 1982: An Evolutionary Theory of Economic Change. Cambridge: Cambridge University Press.

Orsenigo, L. 2006: Clusters and clustering: Stylized facts, issues, and theories, in Braunerhjelm, P. and Feldman, M. (eds.) Cluster Genesis. Oxford: Oxford University Press.

Owen-Smith, J. and Powell, W. 2001: To patent or not: Faculty decisions and institutional success at technology transfer, The Journal of Technology Transfer, 26: 99-114.

Phan, P. and Siegel, D.S. 2006: The effectiveness of university technology transfer, Foundations and Trends in Entrepreneurship, 2: 77-144.

Phelps, R.1998: The effect of university host community size on state growth, Economics of Education Review, 17: 149-58.

Ranga, L. 2003: Structure and Determinants of the Innovative capacity of Academic Research Groups Involved in University-Industry Collaboration. $\mathrm{Ph} \mathrm{D}$. Thesis, University of Sussex.

Romer, P. 1986: Increasing returns and long-run growth, Journal of Political Economy, 94: $1002-1037$.

Romer, P. 1990: Endogenous technological change, Journal of Political Economy, 98: 71102.

Romer, P., 1994: The origins of endogenous growth, Journal of Economic Perspectives, 8: 322.

Rosenberg, N. and Nelson, R. 1994: American universities and technical advance in industry, Research Policy, 23: 325-348.

Rosenthal, S. and Strange, W. 2003: Geography, industrial organization and agglomeration, The Review of Economics and Statistics, 85: 377-393.

Rosser, J.B. 1999: On the complexities of complex economic dynamics, Journal of Economic Perspectives, 13: 169-92.

Saragossi, S. and v. Pottelsberg de la Potterie, B. 2003: What patent data reveal about universities: The case of Belgium, Journal of Technology Transfer, 18: 47-51.

Schmitz, J. 1989: Imitation, entrepreneurship, and long-run growth, Journal of Political Economy, 97: 721-739.

Siegel, D.S., Waldman, D.A. and Link, A.N. 2003: Commercial knowledge transfers 
from universities to firms: Improving the effectiveness of university-industry collaboration, Journal of High Technology Management Research, 14: 111-133.

Siegel, D.S., Waldman, D.A., Atwater, L. and Link, A.N. 2003b: Assessing the impact of organizational practices on the productivity of university technology transfer offices: An exploratory study, Research Policy, 32: 27-48.

Statistics Sweden (SCB), Data from the Central Register of enterprises and establishments, 1975-2002, Stockholm: Statistics Sweden.

Thanki, R. 1999: How do we know the value of higher education to regional development?, Regional Studies, 33: 84-88.

Vetenskapsrådet 2006: Hur mycket citeras svenska publikationer? Stockholm: Vetenskapsrådets rapportserie.

Zucker, L. and Darby, M. 1996: Star scientists and institutional transformation: Patterns of invention and innovation in the formation of the biotechnology industry, Proceedings of the National Academy of Science, 93: 12709-12716. 